\title{
Auditing Marketing Strategy Implementation Success
}

What makes a marketing strategy implementation successful and how can managers measure this success? To answer these questions, the authors developed a two-step audit approach. First, managers should measure the implementation success regarding effectiveness, efficiency, performance outcomes, and strategic embeddedness. Second, they should explore the reasons that have led to success or failure by investigating managerial, leadership, and environmental traps. Doing so will also provide corrective action plans for future implementation efforts.

Dennis Herhausen, Thomas Egger, Cansu Oral 
In order to achieve superior marketing performance, companies must not only develop compelling marketing strategies, but also implement them effectively (e.g., Reeves et al. 2012). Though numerous instruments have been presented to formulate appropriate marketing strategies, managers lack reliable tools to measure implementation efforts properly. Thus, less surprisingly, most strategy failures result from severe implementation pitfalls rather than from inappropriate strategy content (e.g., Galunic/Hermreck 2013). According to an Economist survey among 276 senior managers, only $43 \%$ classified their company as successful strategy executors (Economist Intelligence Unit 2004). This "strategy formulation-implementation gap" is a severe challenge in current managerial practice (Schögel/Herhausen 2012). Indeed, a poorly implemented strategy often results in a sunk costs dilemma (Noble 1999; Heracleous 2000). Hence, if a firm fails to achieve its strategic marketing targets, it must not only assess the strategic content but also the quality of its implementation efforts. Managers detecting strategic performance shortfalls must ask themselves two basic questions: (1) "Is the strategy's content appropriate given the specific market environment?" and (2) "Has everything been done to make the strategy work?"

However, while managers agree on a common understanding of the nature of successful marketing strategies, this seems not to be the case for successfully implemented ones. Indeed, managers lack comprehensive guidelines to determine the outcomes of marketing strategy implementation.

This, in turn, raises two questions:

1. When can a marketing strategy be considered as successfully implemented?

2. How can managers measure the success of the marketing strategy?

\section{Research Approach}

We opted for a qualitative-explorative research approach to find answers on the questions outlined above. First, drawing on an extensive literature review, we analyzed the subject matter from a theoretical perspective. This included a comprehensive conceptual exploration of the factors contributing to, and the defining features of, the notion of implementation success (e.g., Noble 1999; Li et al. 2008). Second, based on a profound theoretical understanding, we developed an all-encompassing conceptual implementation success audit framework. Then, we revised, deepened, and complemented it with findings retrieved from eight expert interviews with managers operating in various industries. The experts work as International Brand Manager, Head of Sales, Head of Marketing, CMO, or Marketing Consultant for companies such as Henkel, Toyota, Manor, or Swiss Life. Our goal was to overcome the deficits of traditional strategy audits and to develop a method that distinguishes between the strategy's content and its implementation, as displayed in figure 1. Third, we confronted the experts subsequently with the overall results to ensure the practical relevance and applicability of our two-step approach.
Prof. Dr. Dennis Herhausen

is Assistant Professor at the Institute of Marketing, University of St. Gallen (HSG), Switzerland

E-Mail: dennis.herhausen@unisg.ch

Thomas Egger

is Junior Brand Manager at Heineken

Switzerland

E-Mail: thomas.egger@mail.com

\section{Cansu Oral}

is Research Assistant at the Institute of Marketing, University of St. Gallen (HSG), Switzerland

E-Mail:cansu.oral@unisg.ch 


\section{Towards a Definition of Marketing Strategy Implementation Success}

Given the complexity of making marketing strategies work, a reliable tool for the determination of implementation success seems essential.

Implementation success is multidimensional since it results from both successful implementation efforts and favorable environmental conditions (Bonoma 1985). Thus, determining implementation success via traditional quantitative and financial performance indicators is problematic for at least two reasons: First, implementation success does not affect quantitative figures directly (e.g., market shares or turnovers). Rather, the outcomes of implementation quality have an impact on quantitative figures with a temporal delay. Further, there is often no direct link between implementation efforts and quan- titative performance indicators, given that factors other than strategy implementation (e.g., market environment) influence quantitative performance indicators. Put simply, traditional performance instruments do not suffice to determine whether strategic performance shortfalls stem from an inappropriate strategy, poor implementation efforts, or both (Mankins/ Steele 2005). Similar problems are associated with performance frameworks developed for strategy implementation (e.g., the Balanced Scorecard; the 7S-framework). While these tools help to manage certain aspects of strategy implementation, they are based on a narrow understanding of strategy implementation success and have substantial deficiencies regarding a reliable analysis of the multidimensional nature of implementation outcomes. Thus, our study yields four overall categories of dimensions reflecting marketing implementa-
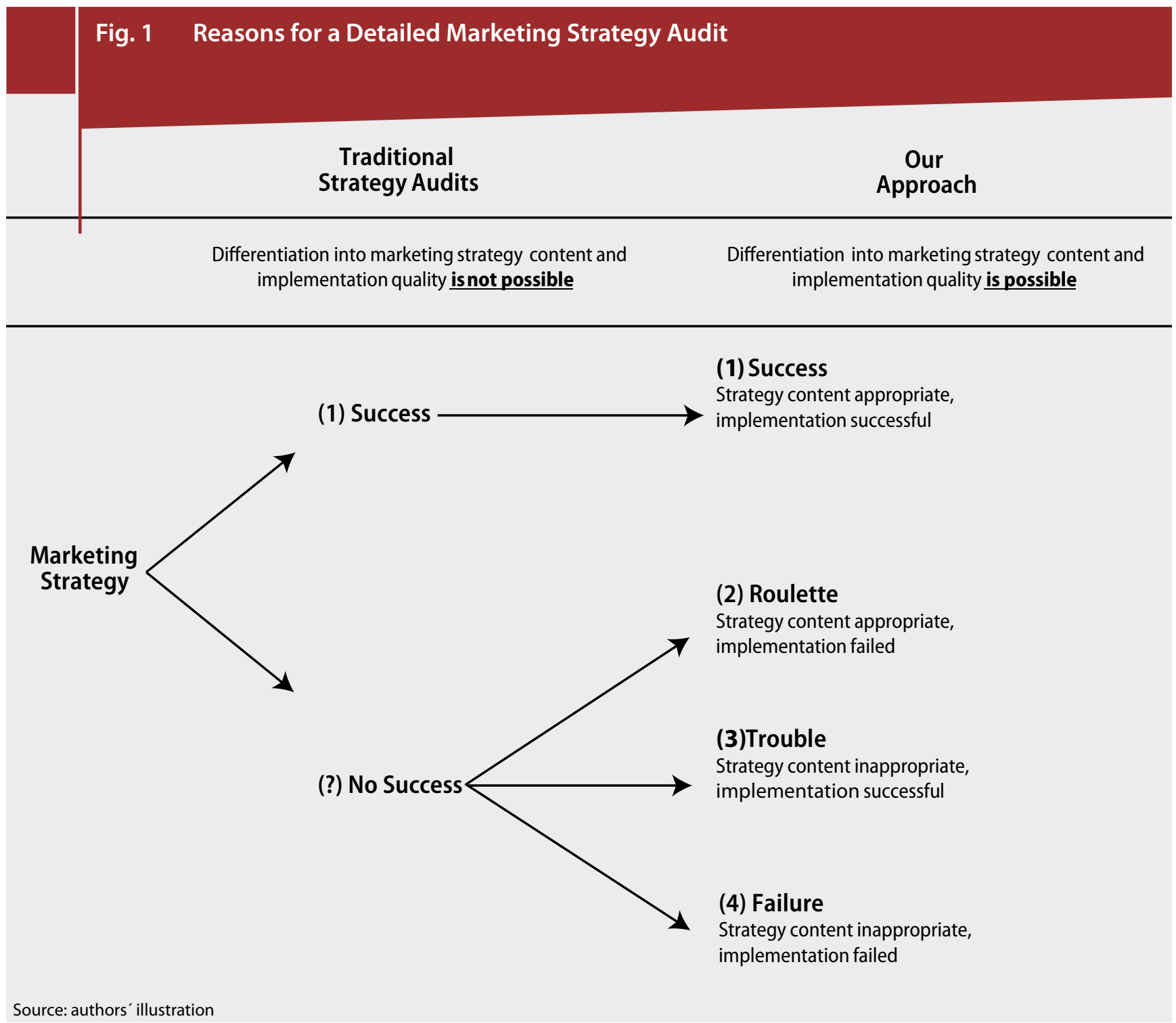
tion success: (1) implementation effectiveness, (2) implementation efficiency, (3) performance outcomes, and (4) strategic embeddedness. All categories consist of sub-dimensions reflecting marketing strategy implementation success. A list of implementation dimensions and the descriptions are listed in figure 2 .

\section{"Implementing a marketing strategy is far more than just putting paperwork into action."}

Given the multidimensional nature of implementation outcomes, a properly conducted marketing audit builds the backbone of a reliable implementation success determination. In general, marketing audits uncover marketing problems systematically and facilitate the formulation of plans to improve marketing performance (see Kotler/Keller 2012 for an introduction into marketing strategy audits). In contrast to conventional marketing controls that focus on retrospective target-performance comparisons, marketing audits allow for future-oriented, feed-forward strategy implications (Tomczak et al. 2009). The statement of one marketing manager indicates what most participants added by way of explanation: "Although it is difficult, you should try to assess implementation efforts apart from your strategy's quality evaluation. The fact

\section{Management Summary}

To date, managers lack comprehensive guidelines to determine the outcomes of marketing strategy implementation. Measuring effectiveness, efficiency, performance outcomes, and strategic embeddedness provides more detailed insights about strategy implementation success. Differentiating between managerial, leadership, and environmental traps sheds light on the reasons that have led to strategy implementation success or failure.

that it is difficult is not an excuse not to do it." Based on our literature review, we have developed a marketing strategy implementation success audit that consists of two steps, performance measurement and performance diagnostic (Kotler/ Keller, 2012).

\section{Marketing Strategy Implementation Success Audit}

\section{First Step: Measuring Implementation Success in Detail}

Retrospectively, the resulting outcomes of a marketing strategy implementation process (implementation success dimensions) should always be checked in detail in order to determine whether or not a strategy has been implemented successfully. The success dimensions listed in figure 2 were

\section{Fig. 2 Dimensions Reflecting Marketing Strategy Implementation Success}

\begin{tabular}{l|l}
\hline Success Dimension & Description
\end{tabular}

Implementation Effectiveness

Goal Achievement

\section{Implementation Efficiency}

Budget Adherence

Time Adherence

Implementation Speed

Performance Outcomes

Market Performance

Strategic Embeddedness

Acceptance of Strategy

Satisfaction with Process

Organizational Commitment

Implementation Learning
Goals and objectives set for the implementation process have been achieved at the end of the implementation process.

Strategy has been carried out within the previously calculated implementation budget. Strategy has been carried out within the previously fixed time schedule and deadlines (no delays).

Overall implementation time span (from beginning to end).

Increase in sales, profit, market share, or other performance indicator.

Implementation outcomes and results are acceptable for those affected by it and do not lead to resistance.

Level of satisfaction with implementation process of those affected by it.

Degree of commitment after implementation of those affected by it compared to pre-implementation commitment.

Building future implementation capabilities due to learning effects. 
derived from our literature review and the expert interviews. As illustrated in figure 3, one must not only take into account the numbers (above the line - hard factors) of strategy implementation, but also the people-oriented implementation outcomes (below the line - soft factors). The results of our study suggest that a reliable implementation audit must ensure an equal weighting of above-the-line and below-the-line dimensions. Nowadays, managers mainly use hard factors to measure strategy implementation. However, psychological elements such as employee resistance and discontent impact a firm's long-term implementation capability negatively. A quote from one of our interviewees illuminates this point: "Employees play an important role. They are of great importance for your sales efforts. If employees are unhappy, they approach your clients in the same way. However, they often are neglected. Employees are your most important assets, as important as money. If a company achieves predetermined im- plementation goals, but loses its employees, you can't really claim that you have successfully implemented a strategy." Another interviewee confirms this: „People have an impact on whether a strategy turns out to be successful or not. Imagine a chain. If one part is missing, it will break."

Hence, if employees do not feel supported, they will not implement the marketing strategy successfully. In order to create employee commitment, top managers should integrate lower echelons into the strategy formulation process. As one interviewee points out: „Often top managers develop strategies without asking middle managers whether the goals are realistic regarding the implementation or not." They also forget that strategy is not static and employee feedback can help to improve it during the implementation phase: „Strategy is alive. Therefore, flexibility is crucial."

Thus, an appropriate audit should include all success dimensions. A mere focus on insufficient market performance

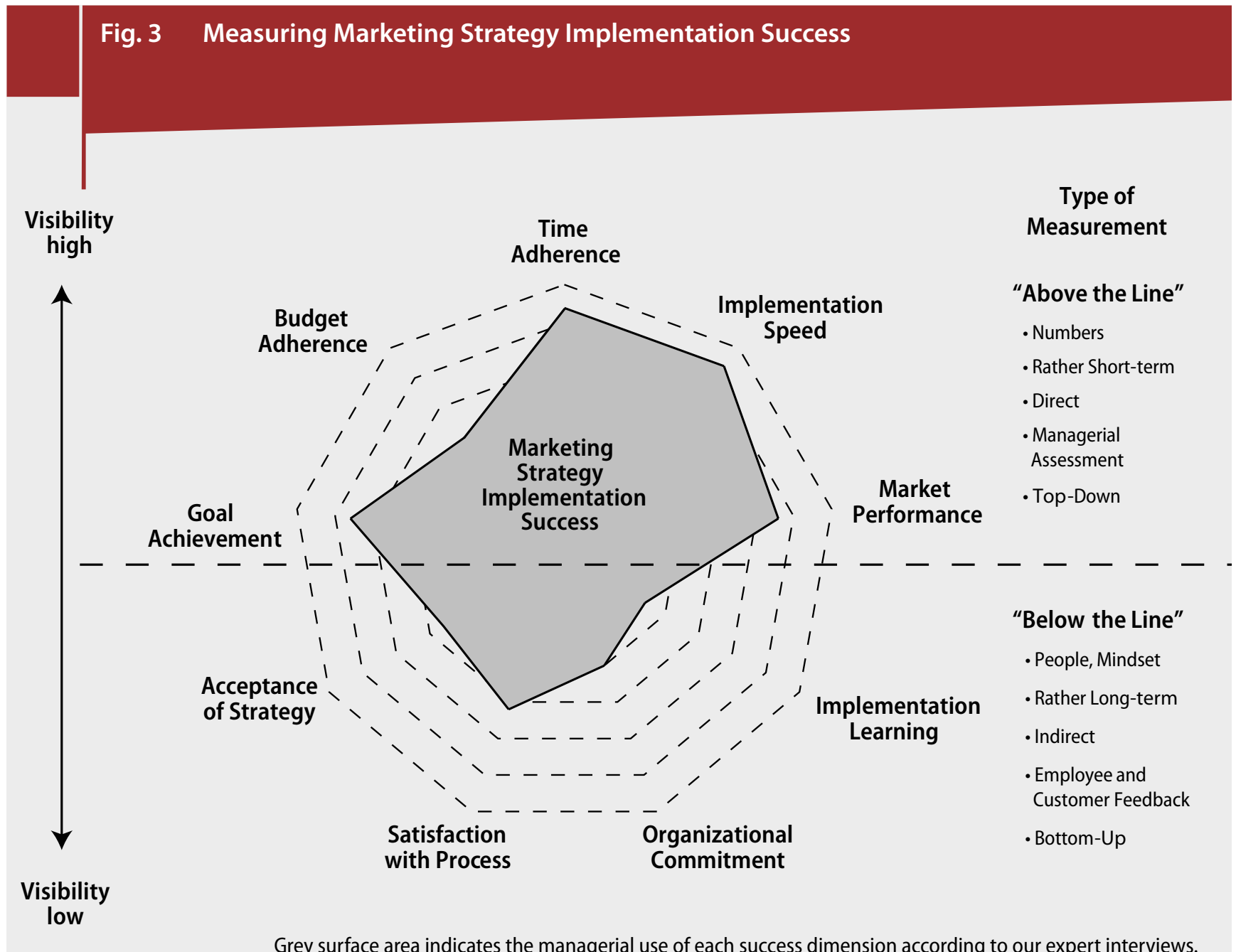

Source: authors' illustration 
cannot answer the question of whether implementation or the marketing strategy itself poses a challenge. Therefore, managers should answer the following questions:

1. Have predetermined goals and objectives been achieved with the strategy?

2. Has the strategy been carried out within the budget?

3. Has the strategy been implemented within the time schedule?

4. Was the overall implementation speed satisfactory?

5. Does the strategy meet performance expectations (e.g., regarding sales, profits etc.)?

6. Do employees who are affected by the strategy accept the implementation outcomes and results?

7. Are employees who are affected by the strategy satisfied with the implementation process?

8. Are employees who are affected by the strategy committed to the organization - even after the implementation?

9. Have future implementation capabilities been acquired in the process?

If some of these questions are answered in the negative, an adjustment is necessary. Also, managers should then uncover

\section{Main Propositions}

- Marketing implementation efforts must be analyzed independently from the content of the underlying marketing strategy.

- Only combined auditing techniques allow for a factual and reliable determination of implementation success dimensions.

- An appropriate audit combines measuring marketing strategy implementation success dimensions and detecting reasons for implementation success or failure.

the pitfalls that have led to this situation. Only a detailed audit will shed light on the question whether the content of a strategy or its implementation caused the failure.

\section{Second Step: Finding the Reasons for Implementation Fail- ure or Success}

Once the different implementation success dimensions have been determined, managers should look for the reasons of im-

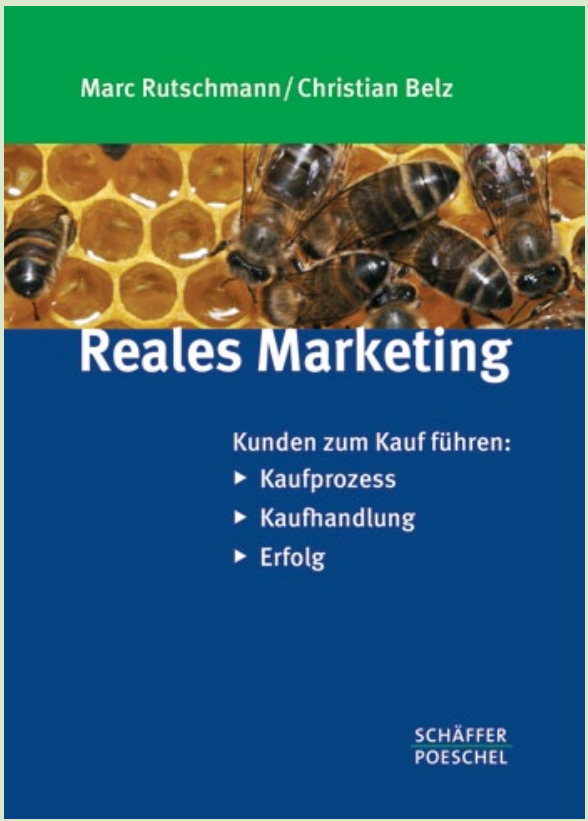

Stuttgart: Schäffer-Poeschel 2014 ISBN 978-3-7910-3339-6, 174 S., geb., CHF 53.90/EUR 39.95 (zzgl. Versand)

www.thexis.ch
Marc Rutschmann/Christian Belz

\section{Reales Marketing}

Wir brauchen reales Marketing, das sich auf reales Kundenverhalten stützt! Kunden gefällt vieles und sie haben zahlreiche Absichten. Nur werden ihre Wege zum Kauf immer länger, verlagern sich häufig, werden abgebrochen, verschoben oder verändert. Es ist deshalb die Kernaufgabe für Marketing und Vertrieb, sehr konkret die realen Kaufprozesse zu erfassen und die Stellhebel zu erkennen, die den Kunden erfolgreich zum Kaufabschluss führen.

Fein ausgedachtes Imagemarketing in der Gedankenwelt des Kunden wird überschätzt. Gut positionierte und attraktive Marken allein bewegen den Kunden selten zur Kaufhandlung. Dieses Buch wendet sich an Entscheider im Marketing, die erkennen, dass herkömmliche Marketingansätze immer weniger wirken. Es ist ein Aufruf an Verantwortliche, die nach neuen und nachhaltigen Konzepten suchen und etwas bewegen wollen. Die Ergebnisse sind empirisch gesichert und zahlreiche Unternehmensbeispiele - von Amazon über Apple, Gillette bis Zara - weisen den Weg.

Es mag übertrieben klingen, aber dieses Buch kann eine Revolution im Marketing bewirken. 
plementation failure or success by auditing the factors affecting implementation. Implementing a marketing strategy is far more than just putting paperwork into action. As a matter of fact, it is a hardly steerable process, which is characterized by a high degree of complexity (Lehner 2004). Both internal and external factors affect a firm's implementation success (e.g., financial crises, consumer slowdowns, economic downturns). While the influence of external factors varies across industries, the findings from our literature review and expert interviews yielded a list of internal factors that contribute substantially to the success or failure of an implementation process, irrespective of the company's market environment or industry type (figure 4). In accordance with common academic conceptualizations (e.g., Noble 1999; Li et al. 2008), these factors can be grouped into either managerial or leadership factors. Companies that steer and manage those factors in a proactive manner significantly increase the chances of implementation success.

\section{"By determining the market}

performance, implementation efficiency, implementation effectiveness, and strategic embeddedness, one can identify the defining features of implementation success.”

A systematic analysis of the reasons for implementation success or failure may facilitate the projection of learnings derived from past efforts onto future implementation plans. As derived from our literature analysis, managerial traps, leadership traps, and environmental traps may lead to strategy failure. Internal

\section{Lessons Learned}

- Managers should measure marketing implementation success in much more detail.

- After measuring marketing implementation success, managers should find the reasons for implementation failure or success.

- Following the proposed approach may help managers to shed light on a marketing strategy's appropriateness and the associated implementation quality. pitfalls affect the quality of implementation, while external pitfalls affect the appropriateness of the strategy content. Here, the following questions may guide the audit:

\section{Avoiding Managerial Traps (Implementation Quality)}

1. Do we have sufficient resources for the implementation?

2. Do the organizational structure and processes fit the new marketing strategy?

3. Is the marketing information system aligned to the new marketing strategy?

4. Are rewards and compensations aligned to the new marketing strategy?

\section{Avoiding Leadership Traps (Implementation Quality)}

5. Does the senior management support the strategy implementation?

6. Do leaders clearly communicate and share information with their employees during the implementation process?

7. Are employees trained for the new marketing strategy?

8. Do employees participate in the strategy implementation process?

\section{Avoiding Environmental Traps (Strategy Content)}

9. Does the marketing strategy match the market position and the perceived image?

10.Is the marketing strategy able to deal with market turbulences?

11. Are competitors' strategic actions considered in the marketing strategy?

12. Have customers' demands, needs, or values changed during the implementation process?

To sum up, a systematic marketing strategy implementation success audit can be described as follows: First, by determining the market performance, implementation efficiency (e.g., implementation within budget), implementation effectiveness (achievement of predetermined goals), and strategic embeddedness (e.g., satisfaction with outcomes), one can identify the defining features of implementation success. Second, one can detect the reasons for implementation success or failure by analyzing managerial, leadership, and environmental factors influencing implementation success (e.g., sufficient resources, senior management support, or competitors' strategic actions). He two audit steps are highly dynamic, interactive, and thus, inseparable from each other. 


\section{Recommendations for Companies}

Drawing on the results of our study, we have elaborated six recommendations that assist managers in becoming professional marketing strategy implementation success auditors.

1. Marketing performance can fall short if the marketing strategy content is inappropriate or the implementation efforts do not succeed. Mostly, however, strategies fail due to implementation flaws. Thus, implementation efforts must be analyzed independently from the content of the underlying marketing strategy.

2. Implementation outcomes are both multidimensional and interrelated. Thus, measuring them via traditional quantitative and financial performance indicators is hardly feasible. Combined auditing techniques, however, allow for a factual and reliable determination of implementation success dimensions.

3. A systematic marketing strategy implementation success audit consists of two steps. First, companies should determine the outcomes of their implementation efforts. This consists of a thorough assessment of different above-theline and below-the-line factors (see figures 2 and 3). While managers can evaluate financial and numerical implementation outcomes via traditional controlling instruments, they should assess soft outcomes via alternative approaches, e.g., employee and customer surveys, feedback discussions, or debriefings.

4. In a second step, companies should detect the reasons for implementation success or failure by looking at different levers of implementation success (see figure 4). Though not directly reflecting the defining features of implementation success, a systematic analysis of success levers allows companies to uncover implementation weaknesses and room for improvement for future implementation efforts.

5. Taking into account the specific situation of a company, either an internal or external auditor may conduct the marketing strategy success audit. Depending on the internal capabilities, companies should decide whether to deploy an external auditor or an internal team. On the one hand,

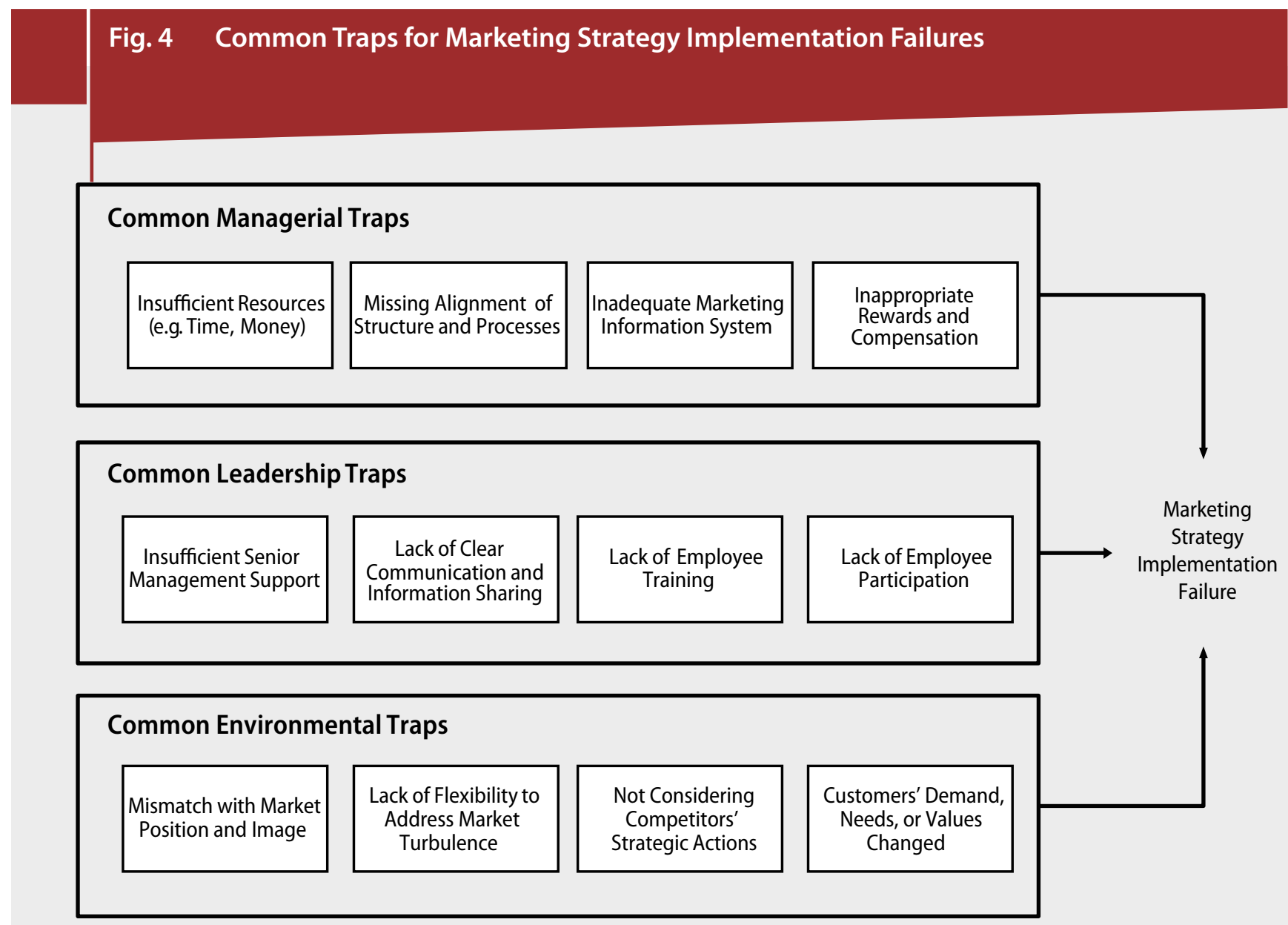

Source: authors' illustration 
external auditors ensure objectivity whereas team-internal implementation auditors are familiar with company structures and relevant marketing skills. On the other hand, there may be internal barriers against external auditors. Therefore, managers should make an elaborated decision. Ideally, the audit could be conducted by an internal team that is supported by a professional auditor.

6. Irrespective of who conducts an implementation success audit, the audit must deliver appropriate implications in order to balance out the costs and resources associated with the audit process. This should include a concise documentation of key learnings and corrective action plans for future implementation efforts.

\section{Conclusion}

The findings from our expert interviews revealed that the application of systematic auditing techniques for the determination of implementation success is not yet common practice. The foremost reasons for this are additional expenditures that come with audits and unavailability of the necessary resources. Instead, more conventional approaches, such as ad-hoc controls, team meetings, debriefings, or financial performance indicators seem to dominate managerial practice. The proposed approach may help to shed light on a strategy's appropriateness and the associated implementation quality. Indeed, most of the participating firms stated that the developed audit framework constitutes a conceivable option for determining implementation success.

\section{References}

Bonoma, T. V. (1985): The Marketing Edge: Making Marketing Strategies Work, New York.

Economist Intelligence Unit (2004): Strategy Execution: Achieving Operational Excellence. http://graphics.eiu.com/files/ad_pdfs/Celeran_EIU_WP.pdf (accessed 10.03.2014).

Galunic, D./Hermreck, I. (2013): How to Help Employees „Get“ Strategy, in: Harvard Business Review, 91, 3, pp. 16-17.

Heracleous, L. (2000): The Role of Strategy Implementation in Organization Development, in: Organization Development Journal, 18, 3, pp. 75-86.

Kotler, P./Keller, K. L./Brady, M./Goodman, M./Hansen, T. (2012): Marketing Management, Harlow: Pearson.

Lehner, J. (2004): Strategy Implementation Tactics as Response to Organizational, Strategic, and Environmental Imperatives, in: Management Revue, 15, 4, pp. 460-480.

Li, Y./Guohui, S./Eppler, M. J. (2008): Making Strategy Work: A Literature Review on the Factors Influencing Strategy Implementation, in: Kellermanns, F. W./Mazzola, F.W. (Eds.): Handbook of Strategy Process Research. New York: Edward Elgar, pp. 252-276.

Mankins, M. C./Steele, R. (2005): Turning Great Strategy into Great Performance, in: Harvard Business Review, 83, 7/8, pp. 64-72.

Noble, C. H. (1999): The Eclectic Roots of Strategy Implementation Research, in: Journal of Business Research, 45, 2, pp. 119-134.

Reeves, M./Love, C./Tillmanns, P. (2012): Your Strategy Needs a Strategy, in: Harvard Business Review, 90, 9, pp. 76-83.

Schögel, M./Herhausen, D. (2012): Customer Centricity - nur eine Frage der richtigen Strategie? in: Jahrbuch Marketing 2012, St. Gallen, pp. 211-213.

Tomczak, T., Kuß, A., Reinecke, S. (2009): Marketingplanung. Einführung in die marktorientierte Unternehmens- und Geschäftsfeldplanung, 6. Aufl., Wiesbaden.

Zusätzlicher Verlagsservice für Abonnenten von „Springer für Professionals | Marketing“

Zum Thema "marketing strategy" implementation

finden Sie unter www.springerprofessional.de 243 Beiträge im Fachgebiet Marketing
Zeitschriftenartikel (23)

Buchkapitel (220)

\section{Sprache}

Deutsch (27)

Englisch (216)
Von der Verlagsredaktion empfohlen

Gustafsson, V., Schwarz, E. J.: Business Modelling and Convergences, in: Diehl, S., Karamsin, M.: Media and Convergence Management, Wiesbaden, 2014, 9-13

www.springerprofessional.de/4429322 
Springer

\section{Vernetztes Wissen}

für Marketing-Experten!

- Die Zeitschrift: hochwertig und wissenschaftlich fundiert

- Das Portal: Digitale Fachbibliothek. Themen-Scout. Knowledge-Manager

- Das Wissen: qualitätsgeprüft und didaktisch aufbereitet

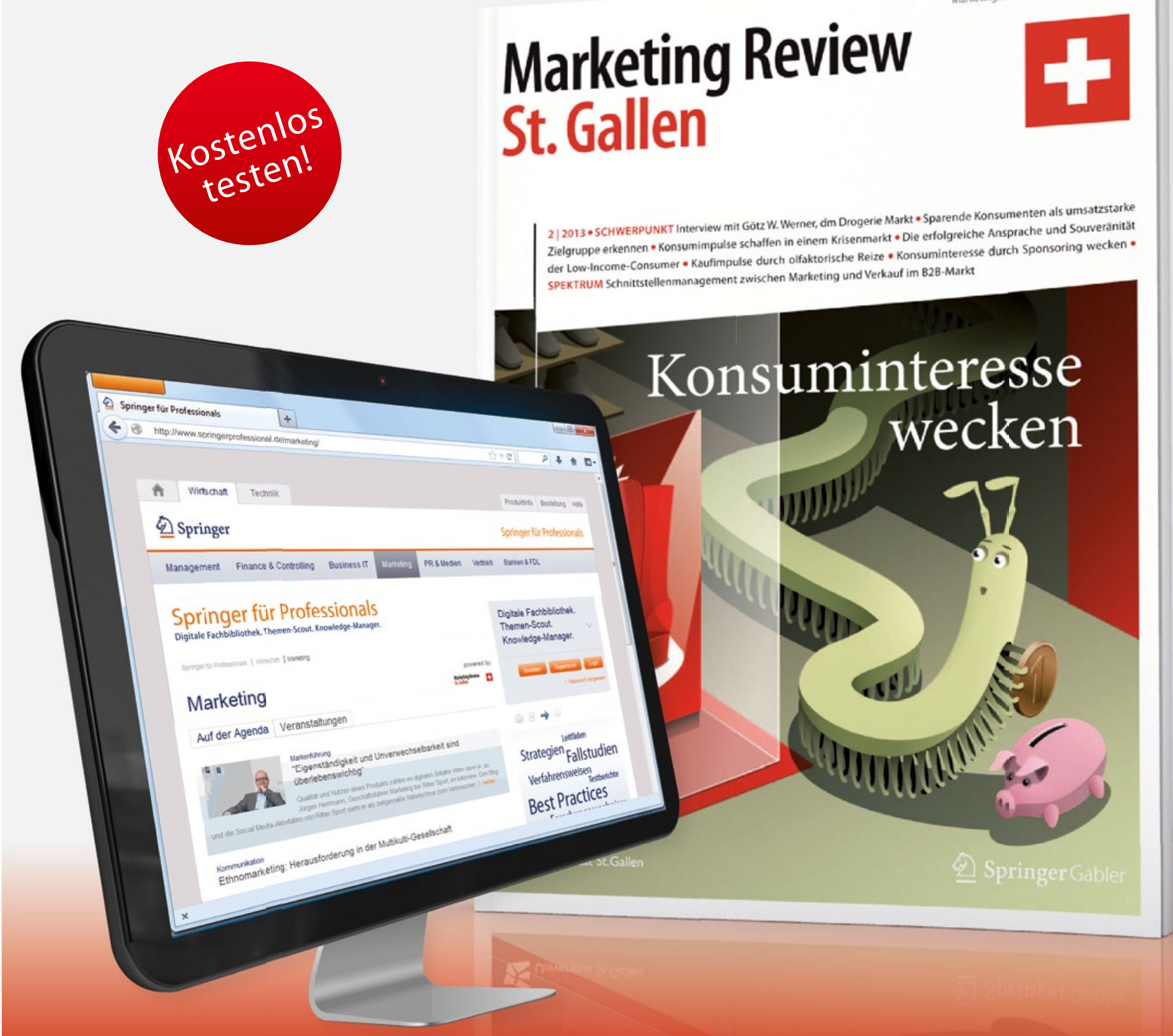

Jetzt kostenlos testen unter: meinfachwissen.de/mrsg 